\title{
Molecular Characterization and Phylogenetic Analysis of Trypanosoma evansi from Local and Imported Camels in Egypt
}

\section{Safaa M. Barghash ${ }^{1 *}$, Ahmed M. Darwish ${ }^{2}$ and Tarek R. Abou-EINaga ${ }^{1}$}

${ }^{1}$ Animal Health Department, Animal Production and Poultry Division, Desert Research Center, Cairo, Egypt

${ }^{2}$ Cell Biology Department, Genetic Engineering and Biotechnology Division, National Research Center, Dokki, Giza, Egypt

\begin{abstract}
Trypanosoma evansi, the agent of trypanosomiasis commonly known as Surra or Guffar, is regarded as one of the most economically important animal parasitic pathogen affecting livestock in Egypt. The current study aims to discuss genetic characterization and phylogenetic analysis of Trypanosoma isolates from local and imported naturally infected camels in Egypt. The study was initially started with parasitological and molecular surveillance on 411 native and 117 imported camels by using PCR- RoTat 1.2 VSG gene targeting $205 \mathrm{bp}$. Further, the molecular characterization and sequencing were achieved on four positive samples using PCR-TR3/TR4 primers that derived from a trypanosomespecific repetitive nucleotide sequence fragment. Product sequences were aligned against the corresponding GenBank sequences of known isolates of $T$. evansi and subjected to phylogenetic analysis. Results revealed that $T$. evansi was present in $66.67 \%$ and $74.36 \%$ of the local and imported camels respectively, regardless of age and sex factors. Basic Local Alignment Search Tool (BLAST) data of the obtained PCR TR3/TR4 gene sequences revealed that they corresponded to those of $T$. evansi, with the homology of $93 \%$ to $99 \%$. Phylogenetic and molecular analyses of this gene showed that three genotypes of $T$. evansi in Egypt are present showed two common SNPs (G136A and G189T) in all samples, two SNPs in ISM and ISD (C3T and A207G) and six SNPs in HSA (T12C, C14T, T15C, G19C, C21G, and $\mathrm{G} 22 \mathrm{C}$ ). We conclude that $T$. evansi is described as presenting genotype variability among its isolates according to geographical distribution in Egypt.
\end{abstract}

Keywords: Trypanosoma evansi; DNA sequencing; Phylogenetic analysis

\section{Introduction}

Trypanosomosis is the most important and serious pathogenic protozoal disease of camel caused in Egypt [1]. There are 11 different pathogenic trypanosomes known to exist in Africa [2]. The subgenus of Trypanozoon comprises three socio-economically important and highly pathogenic African trypanosomes; Trypanosoma brucei, $T$. evansi and T. equiperdum [3]. Neither parasitological nor serological tests are sensitive and specific enough to differentiate between them, thus various kinds of genetic and molecular methods have been continually updated in order to enhance greater precision in the diagnosis of Trypanozoon species and differentiation of these pathogens [4]. In addition, characterization and comparative analysis of genomes of such closely-related T. evansi allow their identification at the strain and may generate a testable hypothesis of genes that might be responsible for differences in pathologies between parasite strains or subspecies [5]. A series of techniques based on PCR have been used for phylogenetic analysis and/or characterization of polymorphisms in T. evansi populations around the world. Minisatellite markers [6,7], and random amplified polymorphic DNA (RAPD) [8,9] evidenced this connection. Similar results have been found by using amplified restriction fragment length polymorphism analysis (AFLP) [10,11], and inter-simple sequence repeat PCR (ISSR) [12]. Few studies have been carried out to investigate whether T. evansi populations are genetically sub-structured using the internal transcribed spacer (ITS) region including (ITS1 and ITS2), that are located between the repeating array of nuclear 18S, 5.8S, and 28S ribosomal RNA genes [13-17]. In addition, diversity of the transferrin receptor-encoding gene located at expression-site-associated (ESAGs 6 and 7) genes [18-21] are utilized in molecular classification of trypanosomes. Those studies demonstrated that the first and second internal transcribed spacers (ITS-1 and ITS2 , respectively) of the rDNA are useful targets for species delineation and for inferring phylogenetic relationships of Trypanosoma spp. with some limitations $[1,16,22,23]$. On the other hand, RoTat 1.2 PCR VSG gene amplified $205 \mathrm{bp}$ is more specific [22], but failed to differentiate some Egyptian strains that have been previously identified as $T$. evansi [24]. Furthermore, targeting the highly repeated sequence of minichromosome satellite DNA (TBR1/2 primer set) was more often seen in the PCR method compared to targeting ITS1 or RoTat 1.2 VSG sequences [16].

In Egypt, thousands of camels are regularly imported from neighboring countries (Libya, Sudan, and Somalia), for the purpose of breeding and slaughter. During their journey in Egypt, they mix with local animals at borders leading to mixed genotyping and strain difference might occur between Egyptian sub-populations and imported strains of T. evansi [10,24]. A few studies on genetic variability and characterization of $T$. evansi isolate in Sudanese originating camels and in other domestic animals were conducted $[10,18,22]$, but the genetic information is lacking in local dromedary camels. The objective of this study was to ascertain the usefulness of sequence analysis of the region targeted by TR3/TR4 in assessing the genetic variability and characterization of Trypanosoma circulating in imported and local camels in Egypt, and as a tool to study phylogenetic and potential relationships of various T. evansi isolates.

\section{Materials and Methods}

\section{Study areas}

The present study requires a comparative analysis of several isolates. Therefore, it was initially started with a spot survey to study the prevalence of T. evansi in both native camels, mostly from nomads at the border

*Corresponding author: Safaa M. Barghash, Parasitology Unit, Animal Health Department, Animal Production and Poultry Division, Desert Research Center, 1-Mathaf El-Mataria St. 11753, El-Naam, P.O. Box 11753, Cairo, Egypt, Tel: +202 26357858; E-mail: barghash_7@yahoo.com

Received May 20, 2016; Accepted July 11, 2016; Published July 18, 2016

Citation: Barghash SM, Darwish AM, Abou-EINaga TR (2016) Molecular Characterization and Phylogenetic Analysis of Trypanosoma evansi from Local and Imported Camels in Egypt. J Phylogenetics Evol Biol 4: 169. doi:10.4172/2329-9002.1000169

Copyright: @ 2016 Barghash SM, et al. This is an open-access article distributed under the terms of the Creative Commons Attribution License, which permits unrestricted use, distribution, and reproduction in any medium, provided the original author and source are credited. 
provinces, and the imported camels from the main abattoirs in Egypt. Six different sites of Egypt located in the Red Sea and Matrouh governorates were selected, where rearing camels are the main activity and T. evansi infections were expected. Regions are the major Egyptian southern and western entrances (from The Sudan and Libya, respectively), where camels are imported legally (Figure 1). Due to migratory communities which usually move from one place to another, regions were grouped as geographic origin of the stocks used in this study.

\section{Animals and blood sample collection}

A total of 528 randomly selected camels (411 native, 117 imported), were examined for trypanosomiasis regardless of ages and sexes during the period from May 2011 to September 2014. Blood samples were collected in Vacutainer tubes containing ethylene di-amine tetraacetic acid (EDTA), and then divided into two parts. One was for microscopical examination and the remaining sample was preserved at $-20^{\circ} \mathrm{C}$ for DNA extraction of trypanosomes for PCR. For parasitological examination, thin blood smears were air-dried, fixed in methanol, stained with a $10 \%$ solution of Giemsa in phosphate-buffered saline ( $\mathrm{pH}$ 7.2), and then subjected to microscopic examination with light microscopy (x40 and oil immersion objectives) according to Njiru [3].

\section{Extraction of genomic DNA and PCR amplification using RoTat1.2 VSG gene}

Genomic DNA from whole blood samples was extracted using a commercially available DNeasy Blood \& Tissue Kit (Qiagen Inc. Germany) according to the manufacturer's instructions. All samples were analyzed with RoTat1.2 PCR depends on detection of a gene for the predominant surface glycoprotein of the T. evansi, and to exclude other trypanosomes [25,26]. Primer sequences were as follows: F5'-GCGGGGTGTTTAAAGCAATA-3',R5'ATTAGTGCTGCGTGTGTTCG-3' (Invitrogen, USA). PCR amplification reaction was performed in a total reaction volume of $25 \mu \mathrm{l}$ containing $50 \mathrm{ng}$ of template DNA and $12.5 \mu \mathrm{l}$ of commercially

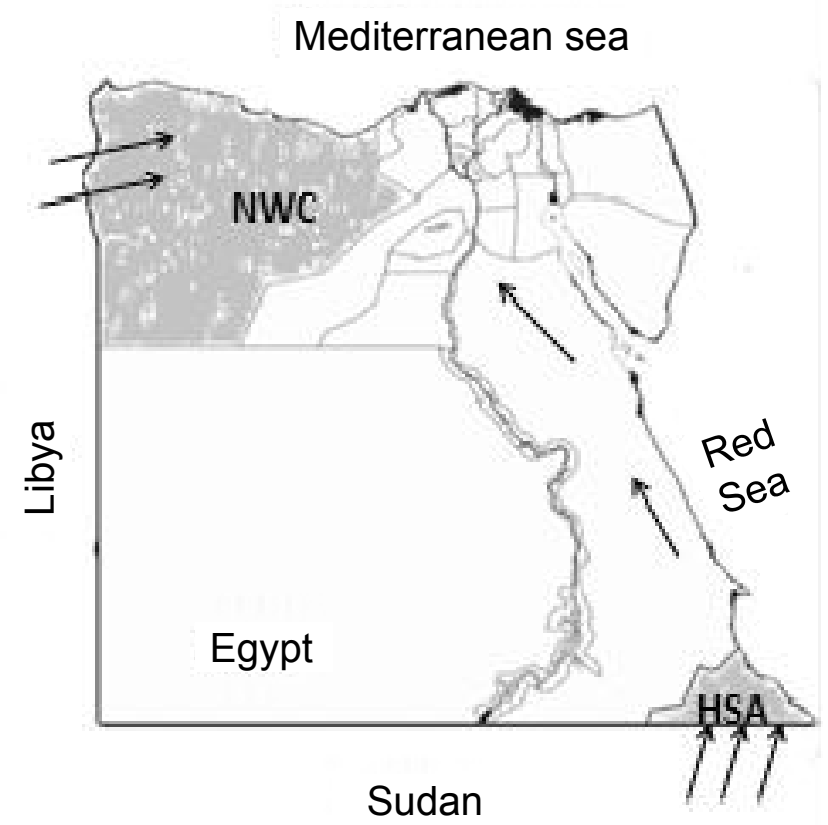

Figure 1: Geographical locations in Egypt where samples were collected from local and imported camels. NWC and HSA are situated in the Northern-West Coast and Southern-East of Egypt. available PCR master mix (Qiagen, Germany). The primers (RoTat1.2) were used at a concentration of $10 \mathrm{pmol} / \mu \mathrm{l}$. The PCR amplifications were carried out in a Biometra thermocycler. Cycling conditions were as follows: initial denaturation $94^{\circ} \mathrm{C} / 3 \mathrm{~min}$ ( 1 cycle), followed by $94^{\circ} \mathrm{C} / 1$ min. (denaturation), $57^{\circ} \mathrm{C} / 1 \mathrm{~min}$. (annealing), and polymerization $72^{\circ} \mathrm{C} / 1 \mathrm{~min}$. (40 cycles), final extension at $72^{\circ} \mathrm{C} / 5 \mathrm{~min}$. Then the product of each sample was electrophoresed through $1.5 \%$ agarose containing ethidium bromide $(1 \mu \mathrm{g} / \mathrm{mL})$, and the voltage was set at $60 \mathrm{~V}$ for the electrophoretic mobility to visualize the amplified DNA and compared to a standard DNA $100 \mathrm{bp}$ (Qiagen, USA).

\section{Statistical analysis}

All the collected data were entered into MS excel spreadsheet program to create a database and filtered before analyzed by using SPSS version 20. Descriptive statistics was used to determine the prevalence of the disease. All statistics were considered significant at $\mathrm{P} \leq 0.05$.

\section{Molecular characterization of T. evansi isolates}

Samples, primers and PCR cycling: Twenty-four positive samples with RoTat1.2-PCR were selected representing imported and local camels. They were divided into four groups containing 6 samples/group (one group produced only a specific band at $205 \mathrm{bp}$ and the other three groups produced from 4-8 multiple bands). The molecular characterization was achieved by T. evansi DNA speciesspecific primers TR3 (5'-GCGCGGATTCTTTGCAGACGA-3') and TR4 (5'-TGCAGACACTGGAATGTTACT-3') (Invitrogen, USA). They were derived from a trypanosome-specific repetitive nucleotide sequence fragment that amplified $257 \mathrm{bp}$ [27]. PCR amplifications were carried out in $50 \mu \mathrm{l}$ reaction mixture containing $100 \mathrm{ng}$ of template DNA and $25 \mu$ of commercially available PCR master mix (Promega, UK). The reaction mixtures were cycled in a programmed PCR machine at the same conditions with RoTat1.2. Further, four of them were submitted to sequencing and phylogenetic analysis.

DNA sequencing and phylogenetic analyses: The four PCR products of amplified specific repetitive nucleotide sequence gene were purified and sequenced in Macrogen, Inc. (Seoul, South Korea). The nucleotide sequences were aligned with existing sequences of T. evansi in the GenBank databases using BLAST programs and databases of the NCBI (National Center for Biotechnology Information, Bethesda, MD, USA) (www.blast.ncbi.nlm.nih.gov/Blast.cgi). Four sets of nucleotide sequence HSA, ISM, ISD and NWC (220 bp) from Egypt were separately aligned against homologous sequences reference in GenBank using ClustalW method in the Bioedit software version 7.2.5. A phylogenetic tree was constructed using maximum parsimony (MP) version 3.3 and neighbor-joining $(\mathrm{NJ})$ algorithms version 3.6a2.1 of Bioedit software [28].

ID of query sequence: DNA sequences generated from this study were blasted to the databases of the GenBank to find the homologous recorded sequences in ID 8W26EU701R, 8W2CZTCD01R, 8W96AJEX01R, and 8YKBM92G013.

\section{Results}

\section{Microscopic examination and PCR detection of T. evansi}

The present study indicated that T. evansi infection was prevalent in the study areas. Regardless of age and sex factors, T. evansi infections in thin blood smears were observed microscopically in samples from the Red Sea governorate 35 (21.6\%), Matrouh governorate 52 (20.9\%) and from abattoirs $28(22.22 \%)$ with low parasitemia levels in most cases. Whereas, the PCR-positive rates for T. evansi in blood samples from 
the Red Sea and Matrouh governorates and from abattoirs were $67.9 \%$, $65.9 \%$, and $74.36 \%$, respectively. All blood smear-positive samples were also PCR-positive for T. evansi parasites with RoTat1.2 even though that having different morphological shapes in camels and in mice inoculated from infected camels (Figure 2). PCR results with RoTat 1.2 primers revealed that many not all local camel strains in HSA produced between four and eight specific bands with molecular weights of $94 \mathrm{bp}$, 205 bp, 355 bp, 429 bp, 553 bp, 861 bp, 1110 bp, and 1526 bp sharing with Sudanese and Somali imported strains in five of them (94 bp, 205 bp, $355 \mathrm{bp}, 429 \mathrm{bp}, 1526 \mathrm{bp}$ ). While, the majority of local camels in Matrouh Governorate of Egypt did not demonstrate these bands, but produced mostly one specific for its genotype with molecular weights of $205 \mathrm{bp}$ (Figure 3). Compared with microscopy of blood smears, the PCR method had higher sensitivity and specificity. Epidemiology and risk factors affecting trypanosomiasis in these regions were discussed in detailed [25,29]. Results of this survey are shown in Table 1.

\section{Genetic characterization}

Genomic DNAs from imported and local camels were amplified producing a single fragment of expected size $(257 \mathrm{bp})$ instead of multiple fragments as in RoTat1.2 amplified $205 \mathrm{bp}$. Sequence Alignments of VSG gene for infected camels from the four different regions yielded 220 base pairs with four stop codon and no gap. The results of sequencing reported existence SNPs between the four different samples where that HSA has 6 SNPs, ISD and ISM have 2 SNPs compare with NWC which mean presence three genotypes as shown in Figure 3. The nucleotide sequences derived from the four PCR products amplifying of four infected camels (ISD, NWC, HSA, and ISM) were released in GenBank with ID 8W26EU701R, 8W2CZTCD01R, 8W96AJEX01R, and 8YKBM92G013, respectively. BLAST data showed different identical from $99 \%$ to $93 \%$ between the sequence of Egypt T. evansi and eight sequences of T. evansi selected globally from GenBank as summarized in Table 2

\section{Phylogenetic analysis}

Phylogenetic analysis exhibited sequence divergence between $T$. evansi from Egypt and eight selected globally from GenBank ranging

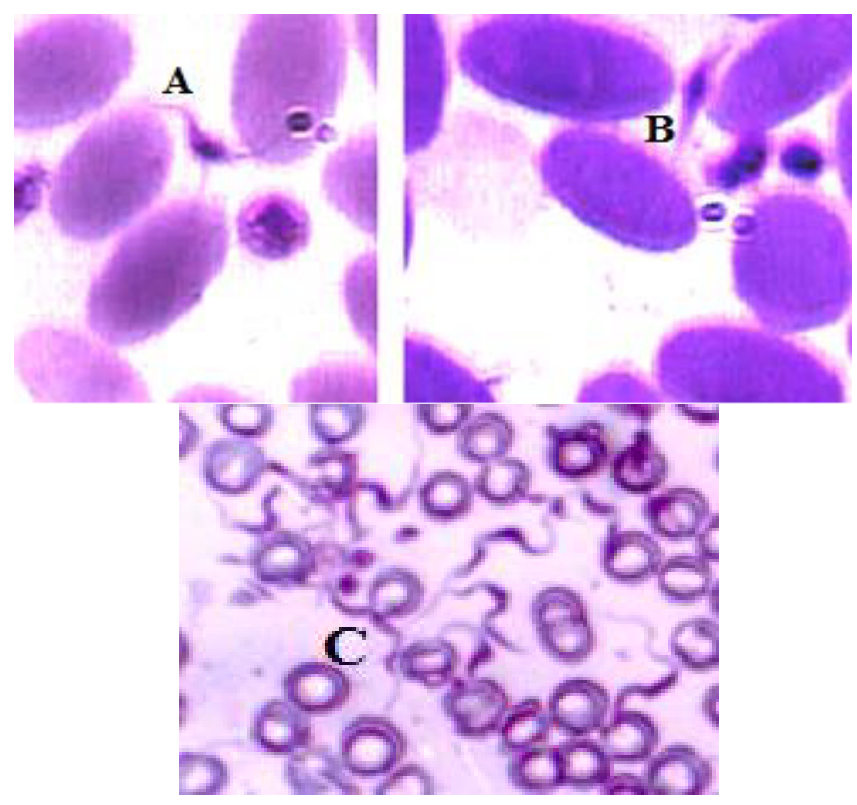

Figure 2: Different morphological shapes for Trypanosoma evansi in camels and in rats inoculated from naturally infected camels.

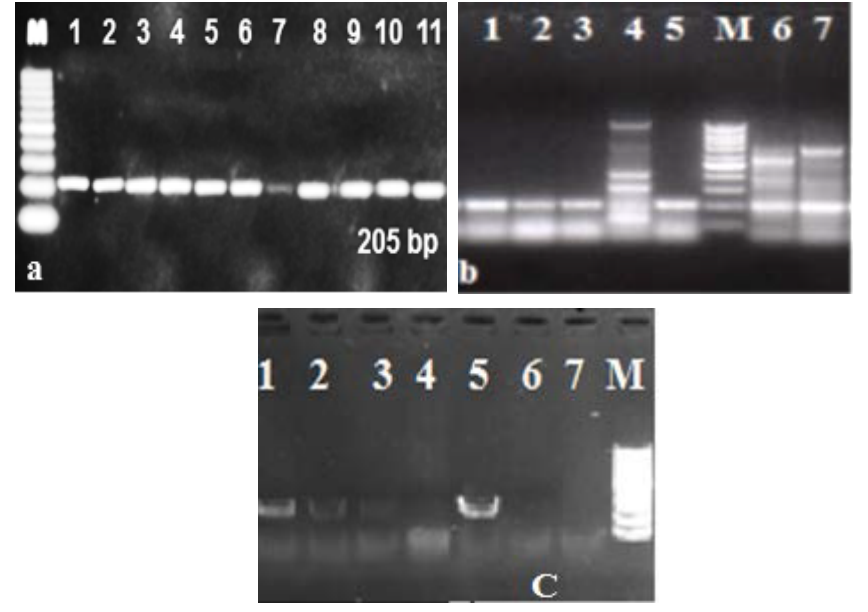

Figure 3: Agarose gel electrophoresis of RoTat 1.2 PCR-based assay products of only $205 \mathrm{bp} \mathrm{(a)} \mathrm{and/or} \mathrm{represent} \mathrm{other} \mathrm{fragments} \mathrm{of} 205 \mathrm{bp}, 355 \mathrm{bp}, 429$ bp, $861 \mathrm{bp}, 1110 \mathrm{bp}, 1526 \mathrm{bp}$ and $1626 \mathrm{bp}$ were amplified from T. evansi (b). Wherever, TR3/TR4 primers amplified only $257 \mathrm{bp}$ in all positive samples. M, 100 bp molecular size marker (Qiagen ${ }^{\circledR}$, Germany).

from $0.9 \%$ to $3.6 \%$. The four isolates gave two common substitutions at G136A and G189T. Whereas the two imported isolates of ISD and ISM gave other two substitutions at C3T and A207G, the local isolate of HSA showed six others of substitutions of T12C, C14T, T15C, G19C, C21G, and G22C as represented in Table 3 and demonstrated in Figure 4. The phylogenetic tree shows also the evolutionary relationship of the sequences in which the length of the branch was proportional to the estimated genetic distance between the sequences (Figure 5). It showed that ISD and ISM identical, also they are close to NWC. The length of the branch is very small between T. evansi strain H4 from Israel and T. evansi from Palestine, strain C6 from Israel, Philippine, Ludhiana, India and Punjab, India. And they are very close to T. evansi from NWC and close to T. evansi from ISM or ISD. Evolutionary distance to each of T. evansi from HSA, American and India strain CIV are large.

\section{Discussion}

In Egypt, T. evansi is the most widespread blood parasite causing significant morbidity and mortality in camels and is given the first priority in its order of importance among camel diseases; in particular, it was presently associated with bacterial and parasitological secondary infections $[29,30]$. In the present study, during the blood collection process, cases of suspected trypanosomiasis were investigated. Despite the survey lasted three years and was conducted at different times of the year in Southeastern and Northwestern Egypt, the prevalence of trypanosomiasis seems to be similar and no significant difference was reported. This may due to lack of health care and veterinary services in the two mentioned regions as previously reported in Egypt [10,26,31]. A similar explanation was reported in Sudan [16]. Compared with microscopy of blood smears, the PCR method had higher sensitivity and was recommended to be utilized in the diagnosis of trypanosomiasis. To study of molecular characterization and phylogenetic analysis of T. evansi isolates from local and imported naturally infected camels in Egypt, we decided to use PCR-TR3/TR4 that amplified $257 \mathrm{bp}$ instead of RoTat 1.2, followed by sequence analysis of this fragment. Whereas, PCR-RoTat1.2 produced mostly several bands other than the specific one (205 bp) in the majority of imported and local camels. This finding is in agreement with the results of $[10,24]$, in addition to the absence of RoTat 1.2 VSG gene in some positive samples with TBR1.2 primer targeting the highly repeated sequence of minichromosome 
Citation: Barghash SM, Darwish AM, Abou-EINaga TR (2016) Molecular Characterization and Phylogenetic Analysis of Trypanosoma evansi from Local and Imported Camels in Egypt. J Phylogenetics Evol Biol 4: 169. doi:10.4172/2329-9002.1000169

Page 4 of 7

\begin{tabular}{|c|c|c|c|c|c|}
\hline \multirow[b]{2}{*}{ Origin (Identity) } & \multirow{2}{*}{$\begin{array}{l}\text { Collection } \\
\text { sites }\end{array}$} & \multirow[b]{2}{*}{ Governorate (Region*) } & \multicolumn{3}{|c|}{ Prevalence of $T$. evansi in camels } \\
\hline & & & No. & $\begin{array}{l}\text { Microscopic } \\
\text { Examination }\end{array}$ & $\begin{array}{c}\text { PCR } \\
\text { (RoTat1.2) }\end{array}$ \\
\hline \multirow{3}{*}{ local } & $\begin{array}{c}\text { Halaib } \\
\text { El Shalateen } \\
\text { Abu-Ramad }\end{array}$ & The Red Sea (Southern East Area) & 162 & $35(21.6 \%)$ & $110(67.9 \%)$ \\
\hline & $\begin{array}{l}\text { Mersa-Matrouh } \\
\text { El-Negeila } \\
\text { Sidi-Barrani }\end{array}$ & Matrouh (Northern West Area) & 249 & $52(20.9 \%)$ & $164(65.9 \%)$ \\
\hline & & Total & 411 & $87(21.17 \%)$ & $274(66.67 \%)$ \\
\hline \multirow{3}{*}{ Imported } & Al-Moneib & Giza & 26 & $5(19.23 \%)$ & $17(65.38 \%)$ \\
\hline & Al-Bassatein & Cairo & 91 & $23(25.27 \%)$ & 70 (76.92\%) \\
\hline & & Total & 117 & $28(22.22 \%)$ & 87 (74.36\%) \\
\hline
\end{tabular}

${ }^{*}$ Collection sites were grouped as geographic regions of the stocks used in this study. No significant differences in $T$. evansi infection have been found between imported and local camels. However, there was a significant difference $(P<0.001)$ between PCR and parasitological tests in detection of $T$. evansi.

Table 1: Prevalence of Trypanosoma evansi in both imported and local camels in Egypt.

\begin{tabular}{|c|c|c|c|c|c|}
\hline \multirow[b]{2}{*}{ Selected Sequences } & \multicolumn{4}{|c|}{ Current Egyptian $T$. evansi isolates } & \multirow[b]{2}{*}{ Reference } \\
\hline & $\begin{array}{c}\text { (ISD) } \\
\text { 8W26EU701R }\end{array}$ & $\begin{array}{c}\text { (NWC) } \\
\text { 8W2CZTCD01R }\end{array}$ & $\begin{array}{c}\text { (HSA) } \\
\text { 8W96AJEX01R }\end{array}$ & $\begin{array}{c}\text { (ISM) } \\
\text { 8YKBM92G013 }\end{array}$ & \\
\hline HM209055.1 (H4 Israel) & $98 \%$ & $99 \%$ & $96 \%$ & $98 \%$ & {$[36]$} \\
\hline HM209054.1 (C6 Israel) & $97 \%$ & $98 \%$ & $95 \%$ & $97 \%$ & {$[37]$} \\
\hline EU931247.1 (Palestine) & $97 \%$ & $98 \%$ & $95 \%$ & $97 \%$ & Unpublished \\
\hline JQ653273.1 (Philippine) & $98 \%$ & $99 \%$ & $96 \%$ & $98 \%$ & unpublished \\
\hline JF894242.1 (American) & $99 \%$ & $95 \%$ & $93 \%$ & $99 \%$ & Unpublished \\
\hline LC008133.1 (CIV India) & $99 \%$ & $99 \%$ & $96 \%$ & $99 \%$ & {$[38]$} \\
\hline JQ0303878.1 (Punjab. India) & $96 \%$ & $97 \%$ & $94 \%$ & $96 \%$ & Unpublished \\
\hline AB979445.1 (Ludhiana, India) & $99 \%$ & $99 \%$ & $96 \%$ & $99 \%$ & [39] \\
\hline
\end{tabular}

${ }^{*}$ Coded isolates: ISD (ID. 8W26EU701R) and ISM (ID. 8YKBM92G013) were from imported camels originated from Sudan and Somali, respectively. Whereas, NWC (ID. 8W2CZTCD01R) and HSA (ID. 8W96AJEX01R) were from local camels originated from northern-west and southern-east Egypt, respectively.

Table 2: The divergence and identity between the current four Trypanosoma evansi isolates from Egypt and eight selected sequences circulating globally from GenBank.

\begin{tabular}{|c|c|c|c|}
\hline Sample & NWC & ISM and ISD & HSA \\
\hline & & & G136A, G189T \\
& & & T12C \\
Substitutions & G136A, G189T & G136A, G189T & C14T \\
& & C3T & T15C \\
& & A207G & G19C \\
& & & C21G \\
\hline
\end{tabular}

Table 3: Substitutions between four isolates of Trypanosoma evansi from Egypt.

satellite DNA [25,32]. These results were explained as (a) occurrence of mutants due to mixed genotyping occurred between some T. evansi isolates with other Trypanozoon (b) presence of T. brucei and/or $T$. equiperdum infection in the Northern West border area of Egypt (c) the present of T. evansi lacking the RoTat 1.2 VSG gene in the study area as reported in Kenya [33].

Whereas, low genotype variability would be present in endemic trypanosomiasis areas as a result of the elimination of virulent trypanosome strains [34]. It is described as presenting genetic variability among its isolates according to geographical distribution [10]. However, those isolates were identified with degrees of heterogeneity, describing that natural populations of T. evansi in Egypt revealed the presence of higher levels of intra-specific genetic variability of T. evansi $[24,35]$. Thus, this study intended to apply TR3/TR4 as a molecular tool to characterize trypanosomes in Egypt. The current search was the third study on T. evansi genotypes in imported dromedary camels in Egypt after $[18,22]$, but it was the first studied T. evansi genotypes in both imported and local camels. A partial sequence of RoTat 1.2 VSG gene was identical to the T. evansi sequences reported from India and Kenya, but the varied similarity was seen when aligned with other Egyptian $T$. evansi sequences [22]. Whilst, analysis of transferrin receptor-encoding gene (ESAG6) showed variable repertoire in the studied isolates, which may indicate to a novel structure of $T$. evansi population from Egypt and/or a difference in host range [18]. In the present study, the results of the phylogenies obtained from the Maximum Parsimony (MP) method suggest that T. evansi isolates from HSA (Egypt), America and CIV (India) are more diverse than other isolates. Phylogenetic analysis showed a robust tree clustering all those from known strains of T. evansi circulating globally and retrieved from GenBank with values at relevant nodes. The phylogenetic tree showed the evolutionary relationship of the sequences in which the length of the horizontal line was proportional to the estimated genetic distance between the sequences. This indicated that the evolutionary distance between groups is very short suggesting that the genetic divergence is recent (Figure 4).

\section{Conclusion}

In conclusion, the present study indicated that surra is highly prevalent in local and imported camels. Though RoTat 1.2 PCR should have been better than any other diagnostic tests for T. evansi, it amplified multiple fragments in some cases than the case of TR3/ TR4-PCR that could detect also those trypanosomes amplifying one fragment. This data could be applicable for the survey of parasite dynamics, epidemiological studies as well as prevention and control of the disease. Moreover, we cloned and sequenced the genes from $T$. evansi isolates from imported and local camels in Egypt and found that the local HSA gene sequences showed obvious differences to those from NWC and other T. evansi sequences from imported camels that were closely related. Consistent with the BLAST results, the phylogenetic tree constructed in this study showed that one newly sequenced $T$. evansi isolate appeared in the same clade as HSA, while the others appeared in the same clade as closely related isolates. 


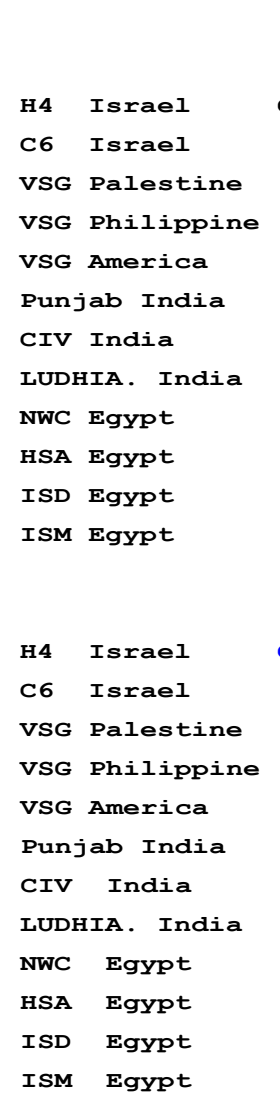

10

20

30

40

50

$\ldots 1 \ldots 1 \ldots 1 \ldots 1 \ldots 1 \ldots 1 \ldots 1 \ldots 1 \ldots 1 \ldots 1 \ldots 1$

GTCAGCTCСтАTTCTTTCGCCGTCCAGTTGTAATGTAAGGGGGTGGCGCT

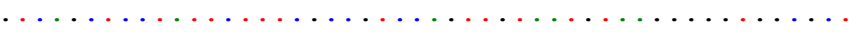

$\ldots \ldots \ldots \ldots$

,

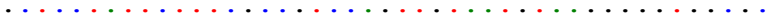

$\ldots \ldots \ldots$. $\ldots$. . . . . . . . . . . . . . .

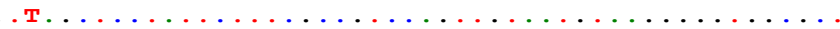

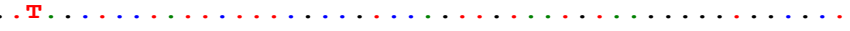

60

70

90

100

$\ldots 1 \ldots 1 \ldots 1 \ldots 1 \ldots 1 \ldots 1 \ldots 1 \ldots 1 \ldots 1 \ldots 1$

CTATACACCCGAAGAGTGTGCACTTTGTTTTCGCTACGTTGACAGACATG

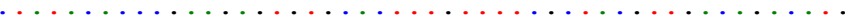

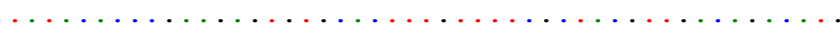

$\ldots \ldots \ldots \ldots \ldots \ldots \ldots \ldots \ldots \ldots \ldots \ldots \ldots \ldots \ldots \ldots \ldots \ldots \ldots \ldots$

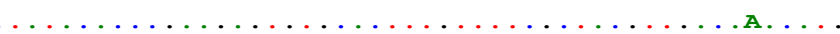

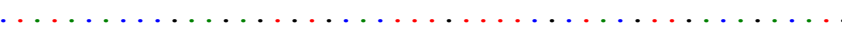

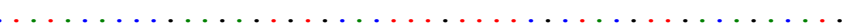

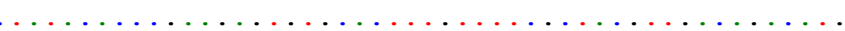

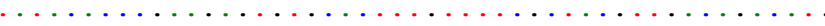

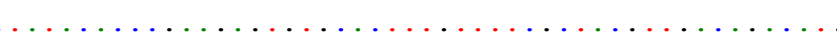

$\begin{array}{lllll}110 & 120 & 130 & 140\end{array}$

$\ldots 1 \ldots 1 \ldots 1 \ldots 1 \ldots 1 \ldots 1 \ldots 1 \ldots 1 \ldots 1 \ldots 1$

AAGTACTCTTTTGACCACTGTAACACCACGTTTAGGCCGCATTGTAGTGT

H4 Israel

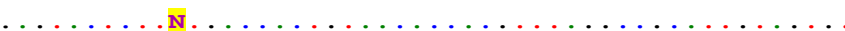

VSG Palestin

VSG Philippine

VSG America

Punjab India

CIV India

IUDHIA. India

NWC Egypt

HSA Egypt

ISD Egypt

ISM Egypt

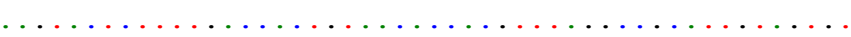

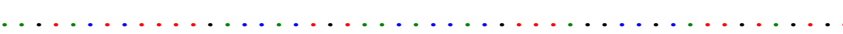

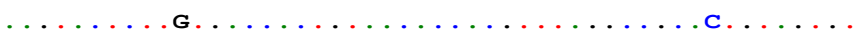

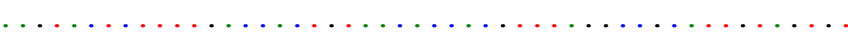

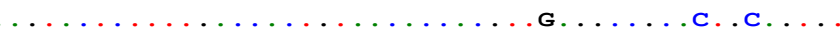

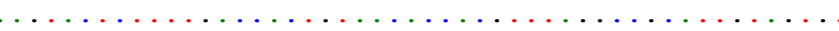

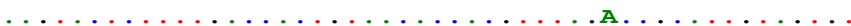

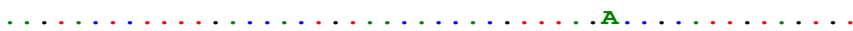

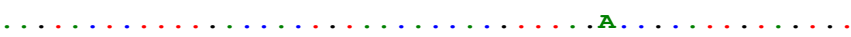

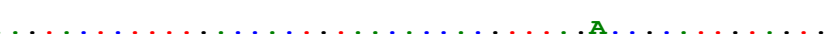

$\begin{array}{lllll}160 & 170 & 180 & 190 & 200\end{array}$

H4 Israel

$\ldots 1 \ldots 1 \ldots 1 \ldots 1 \ldots 1 \ldots 1 \ldots 1 \ldots 1 \ldots 1 \ldots 1 \ldots$

GTGGTTGATGACATCCСTCTCTGTGTGCCTCGCAAGTAGCGTTAGGTCGT

C6 Israel

VSG Palestine

VSG Philippine

VSG America

Punjab India

CIV India

LUDHIA. India

NWC Egypt

HSA Egypt

ISD Egypt

ISM Egypt 
Citation: Barghash SM, Darwish AM, Abou-EINaga TR (2016) Molecular Characterization and Phylogenetic Analysis of Trypanosoma evansi from Local and Imported Camels in Egypt. J Phylogenetics Evol Biol 4: 169. doi:10.4172/2329-9002.1000169

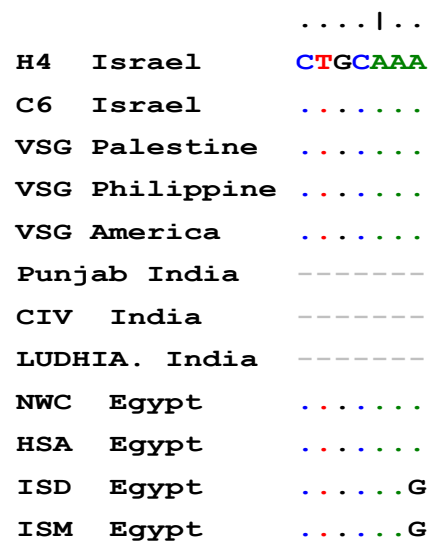

Figure 4: Nucleotide sequence alignment of T. evansi specific repetitive nucleotide sequence fragment from imported and local Egyptian camels with other VSG T. evansi isolates from India, Palestine, Israel, Philippines, and America. Identical bases are shown as dots and sites of variation are shown.

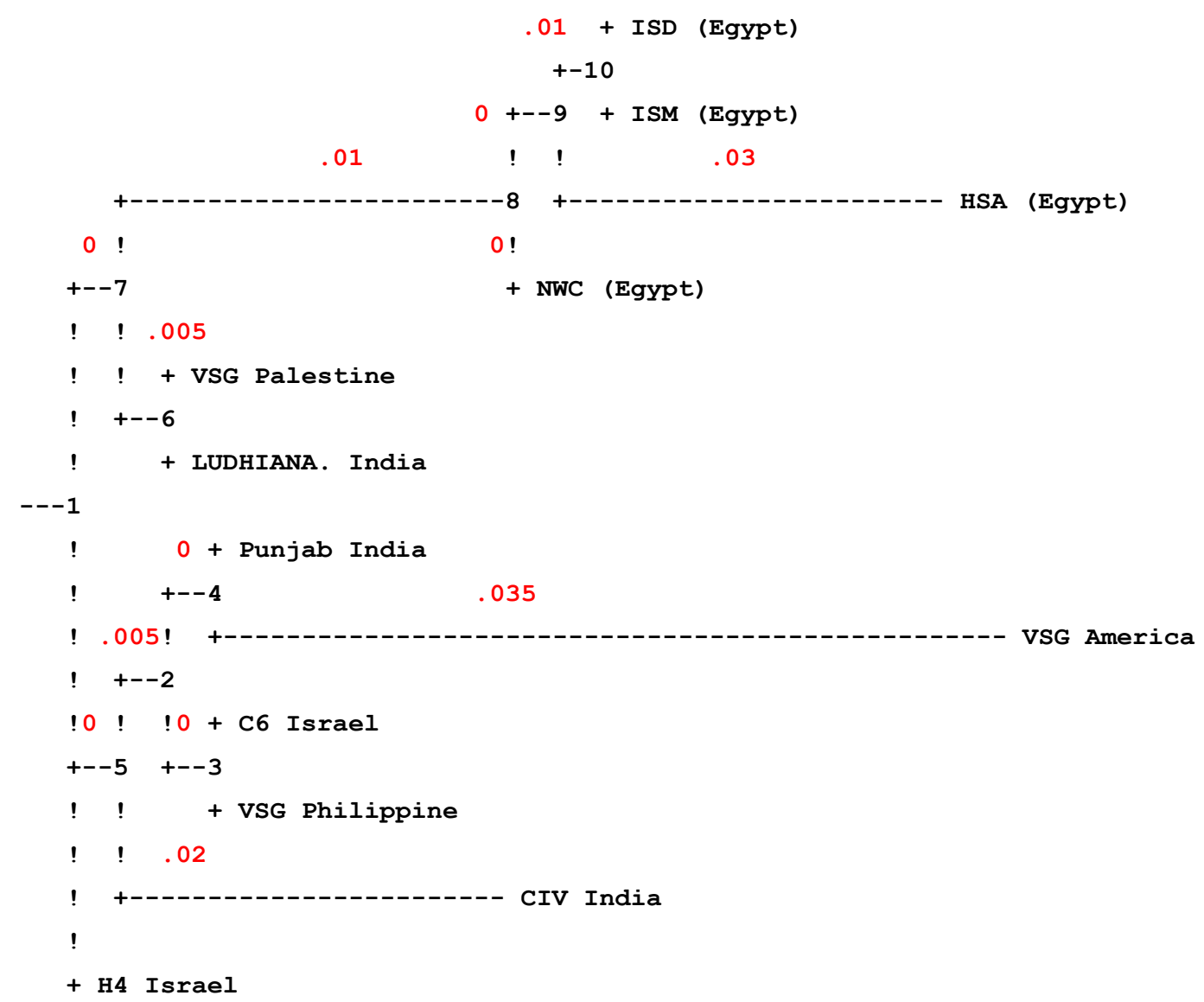

Figure 5: Phylogenetic relationships of $T$. evansi isolates from Egypt compared to reference sequences of different $T$. evansi in database were based on trypanosome specific repetitive nucleotide sequence fragment that amplified $257 \mathrm{bp}$.

\section{Author Contributions}

SB conceived and designed the experiment, contributed reagents/materials/ analysis tools, carried out the molecular analyses, participated in the data analysis, did the field collection, statistical analysis and drafted the manuscript. TA participated in field collection and assisted in obtaining funding. AD helped to conceive the study, carried out phylogenic analysis, PCR cycling, and helped to review the manuscript. All authors read and approved the final manuscript.

\section{Acknowledgements}

The present document was carried out in the frame of PROCAMED project supported and partially funded by the European Union (ENPI-Joint operational Programme of the Mediterranean Basin-IEVP-CT). The contents of this document are the sole responsibility of the 'Division of Animal production, Animal Health Department, Desert Research Center (Egypt) and can under no circumstances be regarded as reflecting the position of the European Union. 
Citation: Barghash SM, Darwish AM, Abou-EINaga TR (2016) Molecular Characterization and Phylogenetic Analysis of Trypanosoma evansi from Local and Imported Camels in Egypt. J Phylogenetics Evol Biol 4: 169. doi:10.4172/2329-9002.1000169

\section{Conflict of Interests}

The authors declare that they have no conflict of interests regarding the publication of this paper.

\section{References}

1. Pourjafar M, Badiei K, Sharifiyazdi H, Chalmeh A, Naghib M, et al. (2012) Genetic characterization and phylogenetic analysis of Trypanosoma evansi in Iranian dromedary camels. Parasitol Res 112: 899-903

2. Njiru ZK, Constantine CC, Guya S, Crowther J, Kiragu JM, et al. (2005) The use of ITS1 rDNA PCR in detecting pathogenic African trypanosomes. Parasito Res 95: 186-192.

3. Njiru ZK, Constantine CC, Gitonga PK, Thompson RC, Reid SA (2007) Genetic variability of Trypanosoma evansi isolates detected by inter-simple sequence repeat anchored-PCR and 302 microsatellite. Vet Parasitol 147: 51-60.

4. Hoare CA (1972) The trypanosomes of mammals. In: A Zoological Monograph Blackwell Scientific Publications, Oxford, UK, pp. 1-749.

5. Wei G, Bull H, Zhou X, Tabel H (2011) Intradermal infections of mice by low numbers of African trypanosomes are controlled by innate resistance but enhance susceptibility to reinfection. Infect Dis 203: 418-429.

6. Agbo EC, Duim B, Majiwa PA, Bucher P, Claassen E, et al. (2003) Multiplexendonuclease genotyping approach (MEGA): a tool for the fine-scale detection of unlinked polymorphic DNA markers. Chromosoma 111: 518-524.

7. Biteau N, Bringaud F, Gibson W, Truc P, Baltz T (2000) Characterization of Trypanozoon isolates using a repeated coding sequence and microsatellite markers. Mol Biochem Parasit 105: 185-201.

8. Salim B, de Meeûs T, Bakheit MA, Kamau J, Nakamura I (2011) Population Genetics of Trypanosoma evansi from Camel in the Sudan. PLoS Neglect Trop Dis 5: e1196.

9. Lun ZR, Li AX, Chen XG, Lu LX, Zhu XQ (2004) Molecular profiles of Trypanosoma brucei, Trypanosoma evansi and Trypanosoma equiperdum stocks revealed by the random amplified polymorphic DNA method. Parasito Res 92: 335-340.

10. Ventura RM, Takeda GF, Silva RAMS, Nunes VLP, Teixeira MMG (2002) Genetic relatedness among Trypanosoma evansi stocks by random amplification of polymorphic DNA and evolution of a synapomorphic DNA fragment for species-specific diagnosis. Int J Parasitol 32: 53-63.

11. Barghash SM (2010) Study of genetic variability and prevalence of Trypanosoma evansi in domestic animals in Egypt. PhD Thesis, Zoology Department, Faculty of Science, Ain Shams University.

12. Masiga DK, Ndungu K, Tweedie A, Tait A, Turner CM (2006) Trypanosoma evansi: genetic variability detected using amplified restriction fragment length polymorphism (AFLP) and random amplified polymorphic DNA (RAPD) analysis of Kenyan isolates. Exp Parasitol 114:147-153.

13. Areekit $S$, Singhaphan $P$, Kanjanavas $P$, Khuchareontawom $S$, Sriyapai $T$ (2008) Genetic diversity of Trypanosoma evansi in beef cattle based on internal transcribed spacer region. Infect Genet Evol 8: 484-488.

14. De Oliveira LA, Da Silva SS, Herrera H, Gama C, Cupolillo E, et al. (2008) Trypanosoma evansi: molecular homogeneity as inferred by phenetica analysis of ribosomal internal transcribed spacers DNA of an eclectic parasite. Exp Parasitol 118: 402-407.

15. Khuchareontaworn S, Singhaphan P, Viseshakul N, Chansiri K (2007) Genetic diversity of Trypanosoma evansi in buffalo based on internal transcribed space regions. J Vet Med Sci 69: 487-493.

16. Barghash SM, Abou El-Naga TR, El-Sherbeny EA, Darwish AM (2014) Prevalence of 350 Trypanosoma evansi in Maghrabi camels (Camelus dromedarius) in Northern-West Coast, Egypt using molecular and parasitological methods. Acta Parasitol Globalis 5: 125-132.

17. Salim B, Bakheit MA, Kamau J, Nakamura I, Sugimoto C (2011) Molecula epidemiology of camel trypanosomiasis based on ITS1 rDNA and RoTat 1.2 VSG gene in the Sudan. Parasit Vectors 4: 31

18. Villareal M, Mingala C, Rivera WL (2013) Molecular characterization of Trypanosoma evansi isolates from water buffaloes (Bubalus bubalis) in the Philippines. Acta Parasitol 58: 6-12.

19. Amer S, Ryu O, Tada C, Fukuda Y, Inoue N, et al. (2011) Molecular-identification and phylogenetic analysis of Trypanosoma evansi from dromedary camels (Camelus dromedarius) in Egypt, a pilot study. Acta Trop 117: 39-46.
20. Isobe T, Holmes EC, Rudenko G (2003) The transferrin receptor genes of Trypanosoma equiperdum are less diverse in their transferrin binding site than those of the broad-host range Trypanosoma brucei. J Mol Evol 56: 377-386.

21. Mekata H, Konnai S, Witola WH, Inoue N, Onuma M, et al. (2009) Molecular detection of trypanosomes in cattle in South America and genetic diversity of Trypanosoma evansi based on expression-site-associated gene 6. Infect Genet Evol 9: 1301-1305

22. Witola WH, Sarataphan N, Inoue N, Ohashi K, Onuma M (2005) Genetic variability in ESAG6 genes among Trypanosoma evansi isolates and in comparison to other Trypanozoon members. Acta Trop 93: 63-73.

23. Elhaiga MM, Youssef Al, El-Gayarc AK (2013) Molecular and parasitological detection of Trypanosoma evansi in Camels in Ismailia, Egypt. Vet Parasito 198: 214-218.

24. Nakayima J, Nakao R, Alhassan A, Mahama C, Afakye K, et al. (2012) Molecular epidemiological studies on animal trypanosomiases in Ghana. Parasit Vector 5: 217.

25. Abou El-Naga TR, Barghash SM, Abdel-Hafez HM, Ashour AA, Salama MS (2012) Evaluation of (RoTat 1.2-PCR) assays for identifying Egyptian Trypanosoma evansi DNA. Acta Parasitologica Globalis 3: 01-06.

26. Claes F, Radwanska M, Urakawa T, Majiwa PA, Goddeeris BM, et al. (2004) Variable surface glycoprotein RoTat $1.2 \mathrm{PCR}$ as a specific diagnostic tool fo the detection of Trypanosoma evansi infections. Kinetoplastid Biol Dis 3: 3.

27. Wuyts N, Chokesajjawatee N, Panyim S (1994) A simplified and highly sensitive detection of Trypanosoma evansi by DNA amplification. The Southeast Asian Journal of Tropical Medicine and Public Health 25: 266-271.

28. Hall T (2013) Biological sequence alignment editor.

29. Abou El-Naga TR, Barghash SM (2016) Blood Parasites in Camels (Camelus dromedarius) in Northern West Coast of Egypt. Bacteriol Parasitol 7.

30. Abdel-Rady A (2008) Epidemiological studies (parasitological, serological and molecular techniques) of Trypanosoma evansi infection in camels (Camelus dromedarius) in Egypt. Vet World 1: 325-328.

31. Barghash SM (2005) Molecular studies on Trypanosoma evansi infecting camels and other susceptible animals in Egypt. M.Sc. Thesis (Parasitology). Faculty of Science, Ain Shams University, Egypt.

32. Masiga DK, Smyth AJ, Hayes P, Bromidge TJ, Gibson WC (1992) Sensitive detection of trypanosomes in tsetse flies by DNA amplification. Int $\mathrm{J}$ Parasitol 22: 909-918.

33. Ngaira JM, Olembo NK, Njagi ENM, Ngeranwa JJN (2005) The detection of non- RoTat1.2 Trypanosoma evansi. Exp Parasit 110: 30-38.

34. Hide G, Welburn S, Tait A, Maudlin I (1994) Epidemiological relationships of Trypanosoma brucei stocks from South-east Uganda: evidence for different population structures in human infective and non-human infective isolates. Parasitol 109: 95-111.

35. Ashour AA, Abou El-Naga TR, Barghash SM, Salama MS (2013) Trypanosoma evansi: Detection of Trypanosoma evansi DNA in naturally and experimentally infected animals using TBR1 and TBR2 primers. Exp Parasitol 134: 109-114.

36. Berlin D, Nasereddin A, Azmi K, Ereqat S, Abdeen Z, et al. (2010) Longitudina study of an outbreak of Trypanosoma evansi infection in equids and dromedary camels in Israel. Vet Parasitol 174: 317-322.

37. Berlin D, Nasereddin A, Azmi K, Ereqat S, Abdeen Z, et al. (2012) Prevalence of Trypanosoma evansi in horses in Israel evaluated by serology and reverse dot blot. Res Vet Sci 93: 1225-1230.

38. Sumbria D, Singla LD, Sharma A, Bal MS, Kumar S (2015) Multiplex PCR for detection of Trypanosoma evansi and Theileria equi in equids of Punjab, India. Vet Parasitol 211: 293-299.

39. Sharma A, Singla LD, Kaur P (2015) Comparative evaluation of agglutination assay with microscopy and polymerase chain reaction for detection of Trypanosoma evansi in bovines of Punjab. Indian Journal of Animal Sciences 85: 1164-1166. 